Agro-Science Journal of Tropical Agriculture, Food, Environment and Extension Volume 15 Number 2 May 2016 pp. $9-14$

ISSN 1119-7455

\title{
COST AND RETURNS ANALYSIS OF CATFISH MARKETING IN ABA SOUTH LOCAL GOVERNMENT AREA OF ABIA STATE, NIGERIA
}

\author{
Njoku*, M.E. and Offor, E.I. \\ Department of Agricultural Economics, Michael Okpara University of Agriculture, \\ Umudike, Abia State, Nigeria \\ *Corresponding author’s email: mariastellanjoku@yahoo.co.uk
}

\begin{abstract}
The study analyzed the cost and returns of catfish marketing in Aba South Local Government Area of Abia State. Specifically, the study ascertained the socioeconomic profile of respondents, ascertained costs, returns and net returns of the marketers, determined the marketing margin, marketing efficiency and market share of participants in the market and estimated the determinants of income from catfish marketing. The constraints militating against catfish marketing were also identified. Multi-stage sampling technique was adopted in sampling 60 catfish marketers for the study. Data were collected using structured questionnaire. Data were analyzed using net returns and regression models. Results showed that majority of the respondents were male within active working age of 37 years. About $72 \%$ of the marketers were married, and $93.3 \%$ of them had formal education. The marketing of catfish was found to be viable as indicated by positive net returns of $\$ 109,539.67$ per month. The coefficient of marketing efficiency was $83.8 \%$, while the market share for wholesalers and retailers was 41.17 and $58.2 \%$, respectively. Result of regression analysis indicated that marketing experience, age, education and quantity of catfish handled were significant at various probability levels. Inadequate capital and high cost of transportation were the major constraints to catfish marketing. It was recommended that catfish marketers should form cooperative society to enhance their access to finance, and the relevant variables that significantly influenced net income should be considered in policy issues.
\end{abstract}

Key words: net income, efficiency, marketers, market share

\section{INTRODUCTION}

Fishes and fish products are of great importance to the diet of people. Catfish (Clarias gariepinus) is a species of fishes and a diverse group of ray-finned fish. Catfish is largely consumed in the country especially due to its rich nutritional and medicinal value. More so, the availability of large coastal area and continental shelf made diverse species available in different localities at affordable prices. Demand for fish globally and particularly in Nigeria has been on the increase with supplies not meeting up the demand (FAO, 2006). With an annual fish demand inNigeria of about 2.66 million tonnes, and a paltry domestic production of about 780,000 tonnes, the demand supply gap stands at staggering 1.8 million tonnes (Oyinbo and Rekwot, 2013). Oparinde and Ojo, (2014) noted that fish has high nutritional value with complete array of amino acids, vitamins and minerals for human healthy growth. Fishes are relatively cheaper sources of animal protein compared to beef, pork and other anmals. Amiengheme (2005) asserted that nutrient from fish is superior to all terrestrial meats such as beef, mutton, pork and chicken and is a rich source of high quality animal protein that contains highly digestible energy. Fishes are also good sources of lysine, leucine, value and arginie as well as thiamine, polyunsaturated fatty acid and fat soluble vitamins A, D, E, K and water soluble vitamins such as B complex, minerals like calcium phosphorus iron, iodine and selenium (FAO, 2006). Ovie and Raji (2006) also stated that fishes contain Omega III fatty acid which is good in treatment of cardiovascular diseases, such as hypertension and arteriosclerosis and as such is preferred as better source of protein for aged people.

Catfish is one of the commercially most important fresh water fish in Africa for many developing nations. Its trade provides a significant level of foreign exchange to the exporting countries, as well as generating employment for the local producers marketers and helps to curb the food insecurity of the populace (FAO, 2006). Ebewore (2013) opined that 
most Nigerians are unable to meet the protein requirement because of their poverty level. The needed protein for growth especially among children has been in short supply due the fact that animal protein is costly. The only alternative cheaper source of protein to bridged the gap of protein deficiency is protein from fish sources that are within reach.

According to Adegeye and Dittoh (1985), marketing is a process that involves the identification of wants and need of consumers and the supply of foods and services that are acceptable, and which satisfy the need and wants of consumers and the entrepreneur/manager at a profit. It involves the transportation of the products in the form most acceptable by the consumers thereby creating various forms of utilities through such economic activities as processing, storage, preservation, transportation, wholesaling and retailing among others. The marketing process of handling and marketing of catfish is very delicate if quality and nutritional value are to be maintained due to its short shelf life.

Efficiency in marketing system is essential for growth and development of the fishery subsector. Marketing efficiency involves the movement of products from the producers to the consumers at the lowest cost consistent with the provision of the services of consumers' desire. It involves technical efficiency and economic efficiency. Furthermore, Adegeye and Dittoh (1985) posit that technical efficiency measures the effectiveness or competences with which the physical aspects of marketing such as sorting, transportation and other activities meant to reduce wastage and deterioration of products are handled while economic efficiency measures the realization of maximum output in monetary terms with a given input or a given level of output from the minimum possible resource input.

In marketing various agencies such as the intermediaries (middlemen) of different levels participate in the marketing activities. These agencies could be facilitators, brokers, transporters, wholesalers and retailers who perform different functions as the products move along the marketing chain from one point to another. Coughlan et al. (2001) stated that the wholesalers and retailers improve marketing efficiency tremendously by reducing distribution cost. The wholesalers and retailer purchase large quantities of goods from the manufacturers but sell only one or few at a time to different customers. They are also intermediaries who reduce the number of transactions by creating assortment and providing a wide range of products in one location so that customers can purchase different items from one seller at a time. Enete (2008) stated that as the number of intermediaries increase the marketing system gets better vertically as each of these specializes on different functions performed by the wholesaler and retailers. These middlemen make profit through the margin difference between producers' price and consumers' price. In spite of the enormous contributions of fishes to the health status of man, in Nigeria the annual demand for catfish far exceeds local production. This is because its production is in the hand of artisans who are resource handicapped. Federal Bureau of statistics (2009) stated that over 800,000 metric tonnes of catfish are imported. With the current situation, the value or figure of import would have increased. This very important sector (marketing) of the economy has suffered neglect as most studies on catfish have been centered on production (Inoni, 2007; Kudi 2008). The government of Nigeria overtime had paid little or no attention to it leaving the sector in the hands of private individuals who cannot afford all that is required for the adequate development and growth of the sector. However, efficiency of catfish marketing can stimulate its production in the country in order to bridge the deficit between local consumption and production. Hence the study (i) described the socioeconomic characteristics of catfish marketers, (ii) estimated the costs, returns and net returns and marketing efficiency of catfish marketers, (iii) ascertained the marketing margin of the marketers, (iv) estimated the factors that influence net returns from catfish marketing, and (v) identified major constraints that militate against catfish marketing.

\section{MATERIALS AND METHODS}

The study was carried out in Aba South Local Government Area (LGA) of Abia State. The area lies between $5^{\circ} 06^{\prime} \mathrm{N}$ and $7^{\circ} 21^{\prime} \mathrm{E}$ in the rainforest zone of Nigeria. It has a population of over 423,852 (NPC, 2007) and has landmass of $49 \mathrm{~km}^{2}$ of Aba. It is bounded by Aba North and Osisioma Ngwa LGAs. Being located in the rainforest zone, it has an average rainfall of about $2000 \mathrm{~mm}$ per annum, a mean temperature of $35^{\circ} \mathrm{C}$ in dry season and $25-28^{\circ} \mathrm{C}$ during rainy season. The people of Aba South are Igbo speaking and their main occupation is agriculture. Aba South LGA comprises six autonomous communities. They are Eziukwu Aba, Nnetu, Asokpoaja, Elu Ohazu, Obuda Aba and Ohabiam autonomous communities.

Multi-stage sampling technique was used in sampling fro respondents. In the first stage, three autonomous communities that are heavily involved in fish production and marketing were purposively selected. In the second stage, two villages were purposively selected from each of the three autonomous communities due to their activities in fish farming making it six villages. Furthermore, two fish markets were randomly selected, from each of 
those villages making 12 markets. Five catfish marketers were randomly selected from the list of fish marketers obtained from the marketing association in each market making a total of 60 marketers used for the study. The sampling frame was 540 fish marketers.

The first and fifth objectives were realized using descriptive statistics such as means and percentages. The second objective on net returns was achieved using net returns model stated thus:

$$
\begin{aligned}
& \mathrm{NR}=\mathrm{TR}-\mathrm{TC} \\
& \mathrm{TC}=\mathrm{TFC}+\mathrm{TVC}
\end{aligned}
$$

where NR is net returns and TC is total cost, then TR is total revenue, TVC is total variable cost, and TFC is total fixed cost.

The third objective was achieved using price spread, net profit margin and marketing margin analysis which were used to estimate the efficiency of the marketing system. The price spread for the various catfish marketing channels adopted from Adesope et al. (2005) is stated thus: Channel 1 is producer's price-cost of purchase minus marketing cost; Channel 2 is wholesale price minus (cost of purchase + marketing cost); and Channel 3 is retailer price cost of purchase plus marketing cost.

The net profit/margin for the various fish marketing channels is the net earnings after paying for all marketing cost as stated by Afolabi (2009) and specified thus:

$$
\mathrm{NM}=\mathrm{PS}-\mathrm{M}
$$

where NM is net margin, PS is price spread for each intermediary, and $\mathrm{MC}$ is marketing cost for each intermediary. Marketing efficiency was determined as the ratio of value added (net return) to total marketing cost.

Market share was determined following Onuoha (2002), whereby it is given as:

$$
M_{s i}=\frac{A_{i}}{\sum A_{i}}
$$

where $M_{s i}$ is market share of seller (i), $A_{i}$ is value of sales by sellers (i) ( $\#$, and $\sum A_{i}$ is total value of sales ( $)$. Sales made by sellers were ranked and their frequencies and cumulative frequencies computed. This reflected which group of traders dominated the market.

The fourth objective on factors influencing net returns on cat fish marketing was achieved using ordinary least square (OLS) regression analysis. The model is stated implicitly as:

$$
\mathrm{Y}=\left(X_{1}, X_{2}, X_{3}, X_{4}, X_{5}, X_{6}\right)
$$

where $\mathrm{Y}$ is net returns, $\mathrm{X}_{1}$ is marketing experience (years), $\mathrm{X}_{2}$ is age (years), $\mathrm{X}_{3}$ is household size (number of persons), $\mathrm{X}_{4}$ is educational level (years), $\mathrm{X}_{5}$ is quantity of fish handled $(\mathrm{kg})$, and $\mathrm{X}_{6}$ is amount of credit used ( $)$.

\author{
A priori expectation: \\ $\mathrm{P}\left(\mathrm{x}_{1}, \mathrm{x}_{3}, \mathrm{x}_{4}, \mathrm{x}_{5}, \mathrm{x}_{6}\right)>0$ and $\mathrm{P}\left(\mathrm{X}_{2}\right)<0$
}

\section{RESULTS AND DISCUSSION Socio-economic Characteristics of Respondents}

The results on the socio-economic characteristics of respondents are summarized in Table 1 According to the table, $65 \%$ of the sampled marketers were males while $35 \%$ were females. This indicates that more male marketers were involved than female marketers. This findings is contrary to the findings of Ali (2008) who stated that fish marketing is dominated by female who are usually more involved in fish processing and marketing. The marketers had a mean age of 37 years with majority of the respondents (71\%) being within the age range of 30-49 years. This implies that most of the marketers were in their middle age which is an important factor in marketing activities. This age bracket is known to be active and energetic to participate in catfish marketing. This agrees with the finding of Ebewore (2013), who observed that those involved in economic activities like fish marketers are in their economic active age and were able to actively participate in the business. The table also shows that majority $(77.7 \%)$ of the marketers were married. This implies that a greater percentage of the marketers had family indicating stability. Stability creates conducive environment for good citizen training, development of personal integrity and for entrepreneurship which is important for efficient use of resources (Nwaru, 2004). The same table shows that $93.3 \%$ of the respondents had formal education and about $68 \%$ of the sampled catfish marketers had tertiary education. This implies that the marketers were very literate and were positioned to take advantage of new marketing techniques and innovation that could boost their businesses. FAO (2006) states that higher education level is synonymous with higher level of business attainment and higher income. The present study also shows that the majority of the marketers had household size of 1-3 persons representing about $45 \%$. A mean household size of 4 persons was obtained. This is a relatively small household size which is desirable and of great economic importance as it will not be too burdensome in terms of upkeep of the household and may also help in supplying labour instead of hired labour. Furthermore, the table shows that catfish marketers had a mean marketing experience of 13 years. This implies that the marketers were well experienced in their business. Hence, they can identify possible problems and are likely to proffer solution. 
Table 1: Summary of the socio-economic characteristics of the catfish marketers

\begin{tabular}{|c|c|c|}
\hline Item & Frequency & Percentage \\
\hline \multicolumn{3}{|l|}{ Sex } \\
\hline Males & 39 & 65.0 \\
\hline Females & 21 & 35.0 \\
\hline Total & 60 & 100.0 \\
\hline \multicolumn{3}{|l|}{ Age (years) } \\
\hline $20-29$ & 13 & 21.7 \\
\hline $30-39$ & 21 & 35.0 \\
\hline $40-49$ & 22 & 36.7 \\
\hline $50-59$ & 4 & 6.7 \\
\hline Total & 60 & 100 \\
\hline Mean & 37.33 & \\
\hline \multicolumn{3}{|l|}{ Marital status } \\
\hline Single & 14 & 23.3 \\
\hline Married & 43 & 71.7 \\
\hline Widow & 3 & 5.0 \\
\hline Total & 60 & 100 \\
\hline \multicolumn{3}{|c|}{ Educational level (years) } \\
\hline Never attended & 4 & 6.7 \\
\hline FSLC & 4 & 6.7 \\
\hline WASSCE & 7 & 18.3 \\
\hline Territory & 44 & 68.3 \\
\hline Mean & 14 & \\
\hline \multicolumn{3}{|l|}{ Household size } \\
\hline $1-3$ & 27 & 45.0 \\
\hline $4-6$ & 23 & 38.3 \\
\hline $7-9$ & 9 & 15.0 \\
\hline $10-12$ & 1 & 1.7 \\
\hline Total & 60 & 100.00 \\
\hline Mean & 4 & \\
\hline \multicolumn{3}{|c|}{ Marketing experience } \\
\hline $1-10$ & 20 & 33.3 \\
\hline $11-20$ & 38 & 63.3 \\
\hline $21-30$ & 2 & 3.3 \\
\hline Total & 60 & 100 \\
\hline Mean & 12.5 & \\
\hline
\end{tabular}

Table 2: Monthly cost, returns and net returns of catfish marketing

\begin{tabular}{ll}
\hline Items & Average Value (N) \\
\hline A: Returns & \\
Revenue from catfish sales & $240,980.33$ \\
B(i): Variable costs & \\
Purchase of catfish & $105,558.17$ \\
Transportation & $1,832.50$ \\
Storage cost & $1,493.42$ \\
Packaging cost & $2,168.58$ \\
Cost of labour & $1,359.42$ \\
Loading and offloading & $2,185.83$ \\
Union charge & $1,657.58$ \\
Feeding & 666.33 \\
Fuel & $1,907.58$ \\
Total variable cost & $118,829.41$ \\
B(ii): Fixed cost & \\
Depreciation of oven & $2,000.00$ \\
Depreciation of generator & $1,700.00$ \\
Depreciation of other equipment (tables, & 322.58 \\
basins, nets) & \\
Rent & $8,516.67$ \\
Total fixed cost & $12,539.25$ \\
Total cost (TVC+TFC) & $131,368.66$ \\
Net returns & $109,539.67$ \\
Marketing efficiency & $83.38 \%$ \\
\hline Source: Field Survey, 2016
\end{tabular}

Source: Field Survey, 2016
Monthly Average Costs, Returns and Net Returns of Catfish Marketing in Aba South Local Government Area of Abia State, Nigeria

Results of the analysis on the monthly net returns of catfish in Aba South Local Government Area of Abia State, Nigeria are shown in Table 2. The monthly average total revenue realized from the sales of catfish was $\$ 240,908.33$. A total cost of $\$ 131,368.66$ comprising total variable cost (TVC) of $\$ 118,8241$ and total fixed cost (TFC) of $\$ 12,539$ was also incurred. The net income was positive at N109,539.67. This implies that the business is profitable, a finding corroborating that of Olasunkanmi and Yusuf (2013). Furthermore the study shows that the marketing system of Catfish was efficient with coefficient of marketing efficiency estimate of $83.38 \%$. This implies that catfish pricing and marketing services were performed at levels acceptable to all participants ranging from producers, middlemen to consumers.

\section{Marketing Margin and Percentage Market Share of the Marketers}

Results on the marketing margin and percentage market share of the wholesalers and retailers of catfish in the study area are presented in Table 3 . The market prices of $1 \mathrm{~kg}$ for wholesalers/producers and retailers were $\$ 700$ and $\$ 1700$, respectively while their margins were 700 and 1000 , respectively. A market share of 41.1 and $58.82 \%$, respectively accrued to the two categories. The retailers had the highest marketing margin and market share. This implies that retailers exercise high economic power on price at the expense of producers.

\section{Determinants of Net Returns from Marketing of Catfish}

Determinants of net returns of marketing of catfish in the study area are presented in Table 4. Multiple regression coefficients of catfish marketing are summarized and also presented in Table 4 . The semi$\log$ functional form was chosen as the lead equation based on the statistical and econometric consideration of the $\mathrm{R}^{2}$ (coefficient of determination) value, which shows the explanatory power of the independent variables; the F-ratio, which shows the goodness of fit of the specified model and the conformity of the significant variables with apriori expectation. The $\mathrm{R}^{2}$

Table 3: Marketing margin analysis of catfish marketing in the study area

\begin{tabular}{lcc}
\hline Item & Retailers & Wholesalers/Producer \\
\hline Measurement & $1 \mathrm{~kg}$ & $1 \mathrm{~kg}$ \\
Market price (N) & 700 & 1700 \\
Marketing margin & 700 & 1000 \\
Marketing share & 41.7 & 58.82 \\
\hline
\end{tabular}


Table 4: Determinants of net returns from marketing of catfish

\begin{tabular}{|c|c|c|c|c|}
\hline & Linear & Exponential & Double log & Semi log+ \\
\hline Intercept & $16952.057^{* * * *}(0.281)$ & $8.528(10.195)^{* * *}$ & $5.811(2.393)^{\text {*** }}$ & $-134722.772(-0.366)$ \\
\hline Marketing experience $\left(\mathrm{X}_{1}\right)$ & $3477.675(1.663)$ & $0.027(3.258)^{* * * *}$ & $0.919(2.641)^{* * * *}$ & $148976.466(1.936)^{*}$ \\
\hline Age $\left(\mathrm{X}_{2}\right)$ & $5263.791(-2.239)^{* *}$ & $-0.015(-0.802)$ & $-0.565(-0.989)$ & $-197593.974(-2.281)^{* *}$ \\
\hline Household size $\left(\mathrm{X}_{3}\right)$ & $9137.745(1.266)$ & $0.035(0.445)$ & $0.024(0.108)$ & $40158.263(1.185)$ \\
\hline Educational level $\left(\mathrm{X}_{4}\right)$ & $-2061.661(-1.090)$ & $0.018(0.892)$ & $0.040(0.172)$ & $44186.40(2.040)^{* *}$ \\
\hline Quantity of fish handled $\left(\mathrm{X}_{5}\right)$ & $1050.928(17.539)^{* * *}$ & $0.006(8.651)^{* * *}$ & $1.415(12.794)^{* * *}$ & $219682.476(13.103)^{* * *}$ \\
\hline Amount of credit $\left(\mathrm{X}_{6}\right)$ & $5431.746(0.068)$ & $5.294-007(0.616)$ & $0.016(0.124)$ & $69950.538(0.367)$ \\
\hline $\mathrm{R}^{2}$ & 0.808 & 0.652 & 0.772 & 0.893 \\
\hline $\mathrm{R}^{-2}$ & 0.787 & 0.687 & 0.795 & 0.881 \\
\hline F-ratio & $37.278^{* *}$ & $19.429^{* *}$ & $34.218^{* *}$ & $73.75^{* *}$ \\
\hline
\end{tabular}

Source: Field survey, (2016). Note: + shows the lead equation; ***significant at 1\%; **significant at 5\%, *significant at $10 \%$

Table 5: Distribution of respondent According to marketing problem

\begin{tabular}{llll}
\hline Variable & Frequency & $\%$ & Rank \\
\hline Market remoteness & 12 & 20.00 & $7^{\text {th }}$ \\
Poor access by road & 26 & 43.33 & $4^{\text {nd }}$ \\
Inadequate capital & 48 & 80.00 & $1^{\text {st }}$ \\
Lack of credit facilities & 10 & 16.67 & $8^{\text {th }}$ \\
Low demand of product & 17 & 28.33 & $6^{\text {th }}$ \\
Damage due to animal and theft & 19 & 31.67 & $5^{\text {th }}$ \\
Poor environmental condition & 12 & 20.00 & $7^{\text {th }}$ \\
High cost of transportation & 42 & 70.00 & $2^{\text {nd }}$ \\
Seasonality of commodity & 7 & 11.67 & $9^{\text {th }}$ \\
Price instability & 32 & 53.33 & $3^{\text {rd }}$ \\
\hline Source: field survey, (2016) ${ }^{* * *}$ multiple responses recorded &
\end{tabular}

Source: field survey, $(2016)^{* * *}$ multiple responses recorded

value of 0.893 was obtained which implies that $89.3 \%$ of total variation in the dependent variable was accounted for by variation in the independent variables. F-ratio was 73.75 and was significant at $1 \%$ probability level. This indicates the goodness of fit of the model and the relevance of the variables fitted into the model. The variables that were significant includes, marketing experience, age, educational level and quantity of catfish handled. Marketing experience and educational level were significant at 10 and $5 \%$, respectively and were positively related to net income. This implies that as marketing experience and education increase, net income also increases. This result corroborates the findings of Offor and Nse-Nelson (2015) who opined that marketing experience has significant influence on net income and marketing efficiency. The coefficient of age was significant at $5 \%$ probability level and negatively related to net income. This conforms to apriori expectation. It also implies that as the marketers' age increases, their net incomes reduce due to the fact that there is reduction in energy and capability of participating in marketing activities as one gets older. The coefficient of educational level was significant at the $5 \%$ level and was positively related to net income. This is in line with a priori expectation because as one's educational level increases, it enables one to access and conceptualize on improved marketing techniques and other related issues capable of enhancing one's performance
(Apata et al., 2010). Quantity of fish handled was significant at $1 \%$ and positively related to net income of the marketers. This denotes that the volume of sales or the number of catfish sold significantly affects the level of net income of the marketers. An increase in quantity of fish $(\mathrm{kg})$ sold in turn leads to increase in net income of the catfish marketers.

\section{Constraints to Catfish Marketing}

The problems faced by the catfish marketers are summarized and presented in Table 5 In the table, the constraint that militate against catfish marketing were identified and ranked. Capital was the most critical constraint as majority $(80 \%)$ of the respondents reported that capital was the major constraint affecting marketing of catfish in the area. It was followed by transportation (70\%). This result conforms to the finding of Akinkali and Jamabo (2011), who opined that unavailability of adequate transport and lack of adequate capital are hindrances to effective distribution of goods from one point to another. Seasonality of commodity (11.67\%) wasthe least problem indicated by the catfish marketers as a constraint to their businesses.

\section{CONCLUSION}

The study examined the marketing efficiency of catfish marketing in Aba South Local Government Area of Abia State. Results showed that the business was profitable in terms of cost and return analysis; also the marketing system was efficient. The most important variables that influenced the net returns of catfish marketing were Marketing experience, Age, Educational level and quantity of fish handled. The major constraints that militate against the business were capital and cost of transportation among others.

Based on the findings of the study the following recommendations were made: Marketers should form marketing cooperative as this would increase their access to credit from financial institution and hence help alleviate the problem of inadequate capital. There should be availability of infrastructure such as good feeder roads that link the rural areas to major cities. 
This would reduce the cost of transportation thereby reducing total cost and increasing net income. Moreover, significant variables such as marketing experience, age, education and quantity of catfish handled should be considered in policy making.

\section{REFERENCES}

Adesope, A.A.A, Awoyinka, Y.A. and Babalola, D.A. (2005). Analysis of marketing margin and efficiency of group marketing in Osun State, Nigeria. ACTASATECH Journal, 4 (2): 1-20

Afolabi, J.A. (2009). An assessment of garri marketing in South -Western Nigeria. Journal of Social Science, 21 (1): $33-38$

Akinkali, J.A. and Jamabo, N.A. (2011). A review of some factor militating against sustainable artisanal fisheries development in Niger delta Nigeria. Asian Journal of Agricultural Sciences, 3 (5): 369-377

Ali, E.A., Gaya, H.I.M. and Jampada, T.N. (2008).Economic Analysis of Fresh Fish Marketing in Maiduguri Gamboru Market and KachallariAlau Dam landing site of North-east Nigeria. Journal of Agriculture and Social Science 6(2):3-5

Apata, T.G., Ogunyinka, A. I., Sanusi R.A. and Ogunwande, S. (2010). Effect of Global Climate Change on Nigeria Agriculture: An Empirical Analysis .A paper presented at the $84^{\text {th }}$ Annual Conference of the Agricultural Economics Society, Edinburgh. $29^{\text {th }}-31^{\text {st }}$ March, pp: 5-20

Amiengheme, P. (2005). The importance of fish in human nutrition. A paper delivered at a fish culture forum, Federal Department of Fish Farmers, Abuja

Coughlan, S.A.T., Anderson, E., Stein, L.W. and ElAnsery, A.I. (2001). Marketing Channels. $6^{\text {th }}$ Edition. New Jerse, USA: Prentice Hall

Ebewore, S.O. (2013). Assessment of the Marketing of Frozen Fish (Iced Fish) in Edo State, Nigeria Asian Journal of Business Management 5(4): 353-357
Enete,A.A. (2008). Vertical differentiation of cassava marketing channel in Africa. Tropicultura, 26 (4): 206-210

FAO Fishstat (2006). FAO fisheries Department, Fishery Information,Data and Statistics Unit. FishstatPlus Universal Software for Fishery Statistical Time Series. Aquaculture Production 1950-2007. Version 230

Inoni, O.E. (2007). Allocative Efficiency in Pond fish Production in Delta State, Nigeria: A Production Function approach. Agricultural Tropical and Subtropical Publication, 40 (4): 27-134

N.P.C. National population Commission (2007). The population Census of the Federal Republic of Nigeria,Analytical Report at the National Population Omission Abuja

Nwaru, J.C. (2004). Rural Credit Market and Arable Crop Production in Imo State of Nigeria Ph.D Dissertation Michael Okpara University of Agriculture Umudike, Nigeria.

Offor, E.I. and Nse-Nelson F.A. (2015). Marketing Efficiency of Poultry Egg in Umuahia South Local Government Area of AbiaState ,Nigeria. International Journal of Applied Research and Technology.4 (6):3-7

Olasunkanmi, N.O. and Yusuf, O. (2013). Resource se efficiency in small scale catfish farming in Ogun State, Nigeria. Sky journal of Agricultural Research 3 (1): $37-45$

Oparinde, L.O. and Ojo, S.O. (2014). "Structural Performance of Artisanal Fish Marketing in Ondo State, Nigeria." American Journal of Rural Development, 2 (1): 1-7. doi: 10.12691/ajrd-2-1-1

Ovie, S.I. and Raji, A. (2006). Food security and poverty alleviation through improved valuation and governance of river fisheries in Africa: Fisheries Co-Management in Nigeria: An Analysis of the Underlying Policy Process Project Report II December pp 5-12.

Oyinbo and Reckwot (2013) .Marketing analysis of smokedried fish in Etsako East Government Area of Edo State, Nigeria Local Net Journal of Agricultural Science 2(3):104-106 